\title{
Constructing the Corporate Social Responsibility Indicators of Professional Sport Organization
}

\author{
Bryan H. Chen ${ }^{1}$, Mei-Hua Chen ${ }^{1}$, Pei-Ni Tai ${ }^{1} \&$ Wan-Chun Hsiung ${ }^{2}$ \\ ${ }^{1}$ Department of Finance, National Changhua University of Education, Changhua, Taiwan \\ 2 Department of Sport and Health Management, Da-Yeh University, Changhua, Taiwan \\ Correspondence: Pei-Ni Tai, Department of Finance, National Changhua University of Education, Changhua, Taiwan. \\ Tel: 886-4-723-2105. E-mail: gracetai0602@gmail.com
}

Received: August 24, 2015

Accepted: September 7, $2015 \quad$ Online Published: September 15, 2015

doi:10.5430/ijba.v6n5p75

URL: http://dx.doi.org/10.5430/ijba.v6n5p75

\begin{abstract}
Corporate social responsibility (CSR) was used as a business strategy to enhance reputation, increase competitive advantage, and reduce risk. The purpose of this study was to construct the CSR indicators of professional sport organization. In-depth interviews and Delphi method were conducted. Professional sport team managers, secretary generals of sport organizations and experts in sport management participated in this research. Results indicated that CSR of professional sport organization contained 4 dimensions, 13 sub dimensions and 56 sub indicators. The main indicators include enhancing the performance of professional sport organization, increasing competitiveness of professional sport organization, protecting stakeholder's interests, obeying the law, complying the collective bargaining agreement, protecting environment, providing safe merchandise and stadium, assisting sport promotion, assisting employees' career development, protecting consumer rights, promoting sport, education and health programs, assisting philanthropy organizations, and enhancing community's life quality.
\end{abstract}

Keywords: corporate social responsibility, professional sport organization, indicators

\section{Introduction}

In recent years, there has been a dramatic proliferation of serious social issues and environmental problems which need government, non-profit organizations, and businesses to seek solutions together. The issues of social responsibility and environmental sustainability has no longer being an underappreciated activities, it becomes a crucial business practices all over the world (Babiak \& Trendafilova, 2011). Commission of the European Communities (2001) defined corporate social responsibility (CSR) as "A concept whereby companies integrate social and environmental concerns in their business operations and in their interaction with their stakeholders on a voluntary basis" (as cited in Dahlsrud, 2008).

Carroll (1979, 1999) proposed four well-known dimensions of CSR as economic, legal, ethical, and philanthropic/discretionary responsibilities respectively. Most people think that economic responsibility is above all business responsibilities. To profit, the enterprises are able to maintain business operations, and then making contributions to the society. Legal responsibility is regarded as the rules and regulations were created in the interests of the majority, thus all businesses are required to comply with. Beyond economic and legal responsibility, ethical responsibility represents the expectations of society, it would be additional activities or operations to the enterprises. Finally, the philanthropic/discretionary responsibility of an enterprise is people expects business to cope with social issues voluntarily, not compelled (Carroll, 1979; Carroll \& Shabana, 2010).

Since CSR practice was not forced by the government, why do companies have willing to spend money on it? Kurucz, Colbert and Wheeler (2008) suggested that companies applied CSR as useful strategies, because it can reduce a company's cost and risk, build up legitimacy and reputation, bolster competitive advantage, and create win-win situation (as cited in Carroll \& Shabana, 2010). As Peloza and Shang (2011) aptly pointed out, the best way to build up corporate identity was to provide CSR activities based on their product categories and attributes.

A growing number of research studies focused on CSR can classify into five types (Taneja, Taneja, \& Gupta, 2011) as follows. Type I discussed the meaning, definition, and model of CSR (Babiak, 2010; Carroll, 1979, 1999, 2010; Dahlsrud, 2008; Godfrey, 2009; Huang, 1994; Plewa \& Quester, 2011; Tu, 2009; Walker \& Parent, 2010). Type II 
identified determinants of CSR (Babiak \& Wolfe, 2009). Type III analyzed actions and practice of CSR (Babiak \& Wolfe, 2006; Babiak \& Trendafilova, 2011; Bravo, Matute, \& Pina, 2012; Inoue \& Kent, 2012; Rosca, 2011; Sheth \& Babiak, 2010; Walker, Kent, \& Vincent, 2010). Type IV measured the impacts of CSR on stakeholders and financial performance (Inoue, Kent, \& Lee, 2011; Walker, Heere, Parent \& Drane, 2010; Walker \& Kent, 2009; Walters \& Tacon, 2010). Finally, type V deliberated measurement of corporate social performance (Duygu, 2009; Giannarakis, Litinas, \& Theotokas, 2011; Tsai, Cheng, \& Chang, 2012; Wood, 2010).

Babiak and Wolfe (2006) analyzed the CSR activities hold by the Super Bowl, found that by doing "good things", sport organizations can not only ease the negative criticism caused by unethical behavior, but enhance their image and reputation. Moreover, Babiak and Wolfe (2009) has pointed out that fans/consumers' enthusiasm of the product (team or game), the unique economic structure of the sport industry, transparency in decision making, and management of stakeholders would impact sport organizations on choosing CSR activities. Besides, sport industry also chooses distinct CSR activities based on geographical location, influence of stakeholders, and business operations of organizations (Walker \& Parent, 2010).

As an emerging industry, professional sport was expected not only pursuing profit but practicing ethics (Huang, 1994). Sheth and Babiak (2010) found that the management in the sport industry believed ethical responsibility is most important of all, and also considered CSR as a strategic requirement for enhancing team's image or reputation. Sports have an incredible power to attract the masses, sport organizations could use it to practice CSR and influence the society positively (Smith \& Westerbeek, 2007). Since sport industry operated distinctively, CSR initiatives in sport organizations had distinctive roles and features differ from other industry (Smith \& Westerbeek, 2007).

Take the example of FC Barcelona. When the new board and management team assumed, they addressed four major strategic objectives: (a) restore team's sporting competitiveness, (b) improve transparency of club governance, (c) increase income by commercial advertisement strategies, and (d) practice CSR to maintain the relationship with society (Hamil, Walters, \& Watson, 2010). As Babiak and Wolfe (2006) suggested, no matter which reason (philanthropy or pragmatism) the management considered, sport organizations should no longer ignore CSR. Thus, the purpose of this study was to construct the CSR indicators of professional sport organization. More specifically, this study was undertaken in order to propose and suggest some practical implications of sport CSR.

\section{Method}

This study gathered materials in the field of CSR, sport and CSR, and CSR indicators, adopting research from Sheth and Babiak (2010), Tsai et al. (2012), Tu (2009), and Turker (2009). We complied a draft of CSR indicators of professional sport organization, it contained 4 dimensions, 13 sub dimensions, and 58 sub-indicators (see Table 1). In order to discuss and modify the draft, three experts are proficient in sport management and familiar with CSR issues were invited to do an interview separately.

Table 1. Original CSR indicators

\begin{tabular}{|c|c|c|}
\hline $\begin{array}{c}\text { Dimensions/ } \\
\text { major indicators }\end{array}$ & Sub-indicators & Sources \\
\hline \multicolumn{3}{|c|}{ 1. Economic responsibility } \\
\hline \multirow{8}{*}{$\begin{array}{l}\text { 1.1. Enhance } \\
\text { performance of } \\
\text { professional sport } \\
\text { organization }\end{array}$} & 1.1.1. increase income and revenue & Tsai et al. (2012) \\
\hline & 1.1.2. map out financial plan & Tsai et al. (2012) \\
\hline & 1.1.3. strengthen cost-benefit & Tsai et al. (2012) \\
\hline & 1.1.4. save cost & Tsai et al. (2012) \\
\hline & 1.1.5. build financial auditing system & Tsai et al. (2012) \\
\hline & 1.1.6. build job rotating system & Tsai et al. (2012) \\
\hline & 1.1.7. practice management by objectives & Tsai et al. (2012) \\
\hline & 1.1.8. map out risk management plan & Tsai et al. (2012) \\
\hline \multirow{2}{*}{$\begin{array}{l}\text { 1.2. maintain } \\
\text { competitiveness of }\end{array}$} & 1.2.1. map out organization development plan & Tsai et al. (2012) \\
\hline & 1.2.2. stabilize merchandise quality & $\mathrm{Tu}(2009)$ \\
\hline
\end{tabular}


professional sport organization
1.2.3. retain employees

1.2.4. build extraordinary team culture

1.2.5. innovate training method

1.2.6. perfect player trading system

1.2.7. build interior performance evaluation

1.3.1. disclosure financial information

1.3.2. disclosure employees salary range

1.3. protect stakeholders' benefits

1.3.3. disclosure government grant

1.3.4. perfect communication channels with stakeholders

1.3.5. perfect the official website

$\mathrm{Tu}(2009)$

$\mathrm{Tu}(2009)$

By authors

By authors

Tsai et al. (2012)

$\mathrm{Tu}$ (2009)

By authors

By authors

$\mathrm{Tu}(2009)$

Tsai et al. (2012)

\section{Legal responsibility}

2.1.1. obey law and regulations

Sheth \& Babiak (2010)

2.1.2. prevent occupational injuries

$\mathrm{Tu}(2009)$

2.1. obey law, regulations, and policy

2.1.3. trade player by fair negotiation

2.1.4. crackdown on corruption and unethical behavior

2.1.5. map out punishments on infringement of a treaty

By authors

2.2.1. process employees' affairs fairly

2.2. conform international labor standards

2.2.2. pay reasonable wage

By authors

2.2.3. provide safe and health working conditions

By authors

2.2.4. value labor rights $\mathrm{Tu}(2009)$

2.3.1. reduce carbon emissions

Turker (2009)

Turker (2009)

2.3.2. reduce waste

$\mathrm{Tu}(2009)$

2.3. environmental protection

2.3.3. reduce exhaustion of natural resources

$\mathrm{Tu}(2009)$

2.4.1. build standard operating procedure

$\mathrm{Tu}(2009)$

2.4.2. control competition quality

$\mathrm{Tu}(2009)$

\begin{tabular}{l} 
2.4. provide safe \\
merchandise and service \\
\hline 3. Ethical responsibility
\end{tabular}

$\begin{aligned} & \text { 3.1. assist domestic sport } \\ & \text { development }\end{aligned}$
a

3.1.1. foster sport talent By authors

By authors

2.4.3. maintain safety equipment on time

$\mathrm{Tu}$ (2009)

2.4.4. control merchandise quality

By authors

$\mathrm{Tu}(2009)$ development

3.1.2. provide professional guidance

$\mathrm{Tu}$ (2009)

3.1.3. assist sport technique development By authors

3.2.1. assist employees' career development

$\mathrm{Tu}(2009)$

3.2. assist employees'

3.2.2. encourage employees study further

$\mathrm{Tu}(2009)$

career development

\begin{tabular}{ll}
\hline 3.2.3. provide life assistance & $\mathrm{Tu}(2009)$ \\
\hline 3.2.4. provide legal consultation & By authors \\
\hline 3.3.1. honest advertise & $\mathrm{Tu}(2009)$ \\
\hline 3.3.2. protect consumer privacy & $\mathrm{Tu}(2009)$ \\
\hline 3.3.3. deal with stakeholders' appeal & $\mathrm{Tu}(2009)$ \\
\hline 3.3.4. avoid unethical behavior & Sheth \& Babiak (2010)
\end{tabular}

3.3. value stakeholders' rights

\section{Philanthropic responsibility}




\begin{tabular}{|c|c|c|}
\hline \multirow{4}{*}{$\begin{array}{l}\text { 4.1. promote sport, } \\
\text { education, and health } \\
\text { program }\end{array}$} & 4.1.1. promote sport in school & Sheth \& Babiak (2010) \\
\hline & 4.1.2. hold sport camp or activity & Sheth \& Babiak (2010) \\
\hline & 4.1.3. assist education activity in school & Sheth \& Babiak (2010) \\
\hline & 4.1.4. promote health program & Sheth \& Babiak (2010) \\
\hline \multirow{4}{*}{$\begin{array}{l}\text { 4.2. assist charity or } \\
\text { social vulnerable groups }\end{array}$} & 4.2.1. donation & $\mathrm{Tu}(2009)$ \\
\hline & 4.2.2. engage in charitable event & Sheth \& Babiak (2010) \\
\hline & 4.2.3. form a charity & Sheth \& Babiak (2010) \\
\hline & 4.2.4. encourage employees to be a volunteer & Turker (2009) \\
\hline \multirow{3}{*}{$\begin{array}{l}\text { 4.3. enhance } \\
\text { community's life quality }\end{array}$} & 4.3.1. concern with community development & $\mathrm{Tu}(2009)$ \\
\hline & 4.3.2. hold community cultural event & $\mathrm{Tu}(2009)$ \\
\hline & 4.3.3. hold cultural exhibition & $\mathrm{Tu}(2009)$ \\
\hline
\end{tabular}

After the draft was modified (see Table 2 and Table 3), we chosen Delphi technique to check the fitness of these indicators, mailed the CSR indicators of professional sport organization survey to 15 experts (included professional sport team managers, scholars, and secretary generals in sport organizations). The respondents rated the issues on a scale from one to five where 1 represented "strongly disagree" and 5 represented "strongly agree". Descriptive statistics (mean, mode, and standard deviation) were computed, the item's mean score under 4 was eliminated.

Table 2. Comparison table of CSR major indicators of professional sport organization

\begin{tabular}{lll}
\hline Dimensions & \multicolumn{1}{c}{ Original major indicators } & \multicolumn{1}{c}{ Revised major indicators } \\
\hline \multirow{2}{*}{$\begin{array}{l}\text { 2. Legal } \\
\text { responsibility }\end{array}$} & 2.1. obey law, regulations, and policy & 2.1. obey law and regulations \\
\cline { 2 - 3 } & 2.2. conform international labor standards & 2.2. obey collective bargaining agreement \\
\cline { 2 - 3 } $\begin{array}{l}\text { 3. Ethical } \\
\text { responsibility }\end{array}$ & 3.1. assist domestic sport development & 2.4. provide safe stadium and merchandise \\
\hline
\end{tabular}

\section{Results}

After we interviewed experts, two sub-indicators were eliminated. Moreover, the mean scores of all indicators are above 4, and the consistency within Delphi technique experts exceeded 70\%. Thus, the CSR indicators of professional sport organization contained 4 dimensions, 13 sub dimensions, and 56 sub indicators. The results are presented in Table 3.

Table 3. Comparison table of CSR indicators of professional sport organization

\begin{tabular}{lll}
\hline \multicolumn{1}{c}{ Original indicators } & \multicolumn{1}{c}{ Revised indicators } & Mean \\
\hline 1.1.1. increase income and revenue & $\begin{array}{l}\text { increase income (e.g. tickets, merchandise) and } \\
\text { revenue }\end{array}$ & 4.53 \\
\hline 1.1.4. save cost & ---eliminated--- & 3.88 \\
\hline 1.1.6. build job rotating system & build human resources management system & 4.53 \\
\hline 1.2.2. stabilize merchandise quality & stabilize competition quality & 4.40 \\
\hline 2.4.2. control competition quality & improve competition quality & 4.53 \\
\hline 3.3.1. honest advertise & ---eliminated--- & 3.85 \\
\hline 4.1.1. promote sport in school & promote sport in school and community & 4.66 \\
\hline 4.1.3. assist education activity in school & assist education activity in school and community & 4.53 \\
\hline 4.3.3. hold cultural exhibition & hold sport exhibition & 4.53 \\
\hline
\end{tabular}




\section{Discussion}

This study constructed CSR indicators of professional sport organization from literature review, in-depth interview, and Delphi technique. The results of Delphi technique addressed 4 dimensions, 13 major indicators, and 56 indicators. The findings are discussed as follows.

The results revealed that Enhance performance of professional sport organization, maintain competitiveness of professional sport organization, and protect stakeholders' benefits appears to be important factors in sport organizations' economic responsibility. The ultimate goal of enhancing performance of professional sport organization was to increase their profitability and stabilize operation, and then make contributions to the society. These findings ties in with earlier work by Carroll and Shabana (2010) that enterprises need to have profitability then fulfill their corporate social responsibility (Carroll \& Shabana, 2010) and Huang (1994) that professional sport organizations have to value players' rights.

The results shown that obey law and regulations, conform international labor standards, environmental protection, and provide safe merchandise and service appears to be important factors in sport organizations' legal responsibility. The rules and regulations were created for the interests of the majority, thus all people, organizations, and enterprises are required to comply with (Carroll, 1979, 1999). These findings are consistent with earlier research by Huang (1994), which the relationship between sport and environment are inseparable, it's every sportsman's duty and responsibility to protect environment.

The results indicated that assist domestic sport development, assist employees' career development, and value stakeholders' rights appear to be important factors in sport organizations' ethical responsibility. From the sport organization managements' point of view, doping and sportsmanship issues are overlapped with hypocrisy, once players' unethical behavior was exposed, many team managers would use CSR (doing good things) to avoid criticism strategically (Sheth \& Babiake, 2010). These findings ties in with earlier work Smart and Rechner (2007), CSR is an important strategy used by organizations to manage their reputation.

The results revealed that promote sport, education, and health program, assist charity or social vulnerable groups, and enhance community's life quality appears to be important factors in sport organizations' philanthropic responsibility. Philanthropic events are most popular CSR practice in professional sport organizations (Sheth \& Babiak, 2010). These findings are consistent with earlier research by Godfrey (2009) that sport organizations already devoted to promote community activities (e.g. stay-in-school initiatives) which have positive impacts to the society. By improving the relationship between sport organizations and local community, it may attain local fans' support, and then willing to buy tickets and merchandise (Sheth \& Babiak, 2010).

\section{References}

Babiak, K. (2010). The role and relevance of corporate social responsibility in sport: A view from the top. Journal of Management \& Organization, 16(4), 528-549.

Babiak, K., \& Trendafilova, S. (2011). CSR and environmental responsibility: Motives and pressures to adopt green management practices. Corporate Social Responsibility and Environmental Management, 18(1), 11-24. http://dx.doi.org/10.1002/csr.229

Babiak, K., \& Wolf, R. (2006). More than just a game? Corporate social responsibility and super bowl XL. Sport Marketing Quarterly, 15(4), 214-222. http://dx.doi.org/10.4236/sn.2014.32018

Babiak, K., \& Wolf, R. (2009). Determinants of corporate social responsibility in professional sport: Internal and external factors. Journal of Sport Management, 23(6), 711-742.

Babiak, K., Mills, B., Tainsky, S., \& Juravich, M. (2012). An investigation into professional athlete philanthropy: Why charity is part of the game. Journal of Sport Management, 26, 159-176.

Bradish, C., \& Cronin, J. J. (2009). Corporate social responsibility in sport. Journal of Sport Management, 23(6), 691-697.

Bravo, R., Matute, J., \& Pina, J. M. (2012). Corporate social responsibility as a vehicle to reveal the corporate identity: A study focused on the websites of Spanish financial entities. Journal of Business Ethics, 107(2), 129-146. http://dx.doi.org/10.1007/s10551-011-1027-2

Carroll, A. B. (1979). A three-dimensional conceptual model of corporate performance. Academy of Management Review, 4(4), 497-505. http://dx.doi.org/10.5465/AMR.1979.4498296

Carroll, A. B. (1999). Corporate social responsibility evolution of a definitional construct. Business \& society, 38(3), 
268-295. http://dx.doi.org/10.1177/000765039903800303

Carroll, A. B., \& Shabana, K. M. (2010). The business case for corporate social responsibility: A review of concepts, research and practice. International Journal of Management Reviews, 12(1), 85-105. http://dx.doi.org/10.1111/j.1468-2370.2009.00275.x

Chang, R. D., \& Fang, C. J. (2006). Effects of the information disclosure and evaluation system on earnings management. The International Journal of Accounting Studies, 42, 1-22.

Chang, S. S., Tsai, C. L., \& Hong, C. W. (2010). The study of career planning of elite athletes in Taiwan (Sac-Exc-098 -01-021). Retrieved from Sports Administration Ministry of Education website: http://www.sa.gov.tw/wSite/public/Data/f1387368854175.pdf

Dahlsrud, A. (2008). How corporate social responsibility is defined: An analysis of 37 definitions. Corporate Social Responsibility and Environmental Management, 15, 1-13. http://dx.doi.org/10.1002/csr.132

FIFA. (2006). FIFA and the environment. Retrieved from Federation Internationale de Football Association web site: http://www.fifa.com/aboutfifa/socialresponsibility/environmental.html

Giannarakis, G., Litinas, N., \& Theotokas, I. (2011). A Delphi study to identify corporate social responsibility indicators: The case of Greek telecommunication sector. Journal of sustainable development, 4(2), 16-32. http://dx.doi.org/10.5539/jsd.v4n2p16

Godfrey, P. C. (2009). Corporate social responsibility in sport: An overview and key. Journal of Sport Management, 23(6), 698-716.

Hamil, S., Walters, G., \& Watson, L. (2010). The model of governance at FC Barcelona: Balancing member democracy, commercial strategy, corporate social responsibility and sporting performance. Soccer \& Society, 11(4), 475-504. http://dx.doi.org/10.1080/14660971003780446

Hong, C. W. (2006). The study of building two major student athletic games' regulations. Quarterly of Chinese Physical Education, 20(4), 49-59.

Huang, F. C. (1994). Economic development and sport ethics. Physical Education Journal, 18, 79-88.

Inoue, Y., Kent, A., \& Lee, S. (2011). CSR and the bottom line: Analyzing the link between CSR and financial performance for professional teams. Journal of Sport Management, 25(6), 531-549.

Inoue, Y., \& Kent, A. (2012). Investigating the role of corporate credibility in corporate social marketing: A case study environmental initiatives by professional sport organizations. Sport Management Review, 15, 330-344. http://dx.doi.org/10.1016/j.smr.2011.12.002

Lee, M. H., \& Hsu, Y. C. (2008). A study of the key success factors of the operational performance of leisure farms from the view point of the balanced scorecard. Taiwanese Agricultural Economic Review, 14(1), 111-148.

NBA (2012). CBA 101: Highlights of the 2011 collective bargaining agreement between the national basketball association (NBA) and the national basketball players association (NBPA). Retrieved from National Basketball Association web site: http://www.nba.com/media/CBA101_9.12.pdf

Peloza, J., \& Shang, J. (2011). How can corporate social responsibility activities create value for stakeholders? A systematic review. Journal of the Academy of Marketing Science, 39(1), 117-135. http://dx.doi.org/10.1007/s11747-010-0213-6

Plewa, C., \& Quester, P. G. (2011). Sponsorship and CSR: Is there a link? A conceptual framework. International Journal of Sports Marketing \& Sponsorship, 12(4), 301-317.

Rosca, V. (2011). Corporate social responsibility in English football: History and present. Management \& Marketing Challenges for the Knowledge Society, 6(2), 327-346.

Sheth, H., \& Babiak, K. M. (2010). Beyond the game: Perceptions and practices of corporate social responsibility in the professional sport industry. Journal of Business Ethics, 91(3), 433-450. http://dx.doi.org/10.1007/s10551-009-0094-0

Smith, A. C. T., \& Westerbeek, H. M. (2007). Sport as a vehicle for deploying corporate social responsibility. Journal of Corporate Citizenship, 25, 43-54. http://dx.doi.org/10.9774/GLEAF.4700.2007.sp.00007

Taneja, S. S., Taneja, P. K., \& Gupta, R. K. (2011). Research in corporate social responsibility: A review of shifting focus, paradigm, and methodologies. Journal of Business Ethics, 101(3), 343-364. 
http://dx.doi.org/10.1007/s10551-010-0732-6

Tari, J. J. (2011). Research into quality management and social responsibility. Journal of Business Ethics, 102(4), 623-638. http://dx.doi.org/10.1007/s10551-011-0833-x

Tsai, P. T., Cheng, T. F., \& Chang, H. C. (2012). A study on constructing performance evaluation indicators for the operation of public museums in Taiwan. Journal of Management, 29(3), 187-206.

Tu, I. L. (2009). A study on develop indicator for corporate social responsibility (Unpublished doctoral dissertation of master's thesis). Lunghwa University of Science and Technology, Taoyuan city.

Turker, T. (2009). Measuring corporate social responsibility: A scale development study. Journal of Business Ethics, 85(4), 411-427. http://dx.doi.org/10.1007/s10551-008-9780-6

Walker, M., \& Kent, A. (2009). Do fans care? Assessing the influence of corporate social responsibility on consumer attitudes in the sport industry. Journal of Sport Management, 23(6), 743-769.

Walker, M., \& Parent, M. M. (2010). Toward an integrated framework of corporate social responsibility, responsiveness, and citizenship. Sport Management Review, 13, 198-213. http://dx.doi.org/10.1016/j.smr.2010.03.003

Walker, M., Heere, B., Parent, M. M., \& Drane, D. (2010). Social responsibility and the Olympic Games: The mediating role of consumer attributions. Journal of Business Ethics, 95(4), 659-680. http://dx.doi.org/10.1007/s10551-010-0445-x

Walker, M., Kent, A., \& Vincent J. (2010).Communicating socially responsible initiatives: An analysis of U.S. professional teams. Sport Marketing Quarterly, 19(4), 187-195.

Walter, G., \& Tacon, R. (2010). Corporate social responsibility in sport: Stakeholder management in the UK football industry. Journal of Management \& Organization, 16(4), 566-586. http://dx.doi.org/10.5172/jmo.2010.16.4.566

Wood, D. J. (2010). Measuring corporate social performance: A review. International Journal of Management Review, 12(1), 50-84. http://dx.doi.org/10.1111/j.1468-2370.2009.00274.x 